\title{
The effect of rolled rape seeds on milk composition and lactational responses
}

\author{
W. Nowak and A. Potkański \\ Institute of Animal Nutrition and Feed Management, \\ August Cieszkowski Agricultural University \\ Wolyńska 33 , 60-637 Poznań, Poland
}

(Received 9 December 1999; accepted 15 July 2000)

\begin{abstract}
Forty-five multiparous cows (74-146 d after calving) were blocked into 3 groups of 15 animals on the basis of calving date and milk yield. Within each group the cows were allotted at random to treatment sequences in a $3 \times 3$ Latin square design. Cows were fed a ration composed of pasture, maize silage and meadow hay. Treatments were: control (CK), $6 \mathrm{~kg}$ concentrate without rolled rape seeds (WRS), MR - $5 \mathrm{~kg}$ concentrate and $0.7 \mathrm{~kg}$ WRS and HR $-4 \mathrm{~kg}$ concentrate and $1.4 \mathrm{~kg}$ WRS. The administration of $1.4 \mathrm{~kg}$ (HR) rolled rape seeds per cow insignificantly increased the daily milk yield by $1.2 \mathrm{~kg}$ and milk fat content. Supplemental fat tended to nonsignificantly decrease the percentage protein content in milk (CK, 3.10, MR, 3.03, HR, 3.04), but the total daily protein production was not affected by treatment. Rolled rape seeds affected the fatty acid composition of milk fat. There was a significant $(\mathrm{P}<0.05)$ increase of $\mathrm{C} 18: 1$ and $\mathrm{C} 18: 3$ content as a result of adding WRS, but no effect on $\mathrm{C} 18: 2$ concentration.
\end{abstract}

KEY WORDS: cows, rolled rape secds, milk composition, fatty acids

\section{INTRODUCTION}

Consumers today are more health-conscious and demand dairy products lower in milk fat, especially saturated fatty acids. Dietary manipulation is onc of the methods used to alter the fatty acid composition of milk. The ideal milk fat, based on current recommendations, would contain $>10 \%$ polyunsaturated fatty acids, $>82 \%$ monounsaturated fatty acids and $<8 \%$ saturated fatty acids (Bacr, 1991). Recent studies confirmed the possibility of increasing the concentration of unsaturated fatty acids in milk by providing cows unsaturated fats fed with plant seeds, 
soyabean, sunflower, and cotton seeds. Full fat oilsecds have mainly been used for dairy cows: whole sunflower seeds (Rafalowski and Park, 1982), whole cottonseeds (Coppock et al., 1987), evening primrose seeds (Oenoethera paradoxa) (Strzetelski et al., 1999), rape seeds (Murphy et al., 1987; Strzetelski et al., 1992, 1998).

Fat supplements are often added to dairy rations during lactation when milk energy exceeds energy consumed. Fat addition increases the efficiency of fat utilisation, enhances the lipogenic:glucogenic ratio, and increases the concentration of energy in the diet without decreasing its fibre content (Palmquist and Jenkins, 1980). However, results from feeding trials that were designed to assess supplemental fat are so far inconsistent. Fats have been reported to inhibit fermentation, particularly crude fibre (Kowalczyk et al., 1977; Nowak, 1997), reduce roughage intake (Steele, 1985), and change the acetate:propionate ratio leading to a decrease in milk fat content. Development of ruminally inert fats (Ca-salts, prilled fat) has partially overcome some negative effects of normal fats (oils, tallow) on ruminal fermentation. However, inert fats usually are more expensive than normal fats. Utilisation of whole rape seed by ruminants without chemical treatment with $\mathrm{NaOH}$ or $\mathrm{H}_{2} \mathrm{O}_{2}$ ( Hussein ct al., 1996) is limited by the thick seed coat. Rolling rape seeds could be an inexpensive method of preparing these seeds. Because of the slow liberation of oil from rape seeds, this treatment could only slightly interfere in rumen fermentation while permitting enzymatic digestion in the small intestine and modification of milk fat fatty acid composition.

The objective of the study was to examine the effect of replacing concentrate by rolled rape seeds (WRS) from the Polish double improved variety Jantar, on milk production, milk fat and protein contents and on the fatty acid composition of milk fat.

\section{MATERIAL AND METHODS}

Forty-five multiparous cows (74-46 d after calving) were blocked into three groups of fifteen animals on the basis of calving date and milk yicld. Within cach group the cows were allotted at random to treatment sequences in a Latin square design. Rolled whole rape seeds (WRS) $0.0,0.7 \mathrm{~kg}$ and $1.4 \mathrm{~kg}$ were offered in $3 \times 3$ Latin square design with 21 day periods. Treatments were: control (CK) $-6 \mathrm{~kg}$ concentrate without WRS, MR $-5 \mathrm{~kg}$ concentrate and $0.7 \mathrm{~kg}$ WRS, and $\mathrm{HR}-4 \mathrm{~kg}$ concentrate and $1.4 \mathrm{~kg}$ WRS. One $\mathrm{kg}$ of concentrate was replaced by $0.7 \mathrm{~kg}$ of WRS because of the higher concentration of energy and protein in rape seeds than in concentrate. The nutritive values of feeds (energy value UFL, protein digestible in the intestine PDIE, and PDIN) were calculated according IZ-INRA (1997) using INWAR ver. 1.0 . 
The forage portion of each diet consisted of pasture, maize silage and meadow hay. Grass pasture intake was measured once a week for all experimental cows according to Gawęcki (1994), and intake of hay and maize silage individually every day. Maize silage, concentrate and meadow hay were sampled weekly throughout the experiment and frozen at $-20^{\circ} \mathrm{C}$. Samples were combined into period composites and dried at $50^{\circ} \mathrm{C}$. Dry matter, crude protein, ether extract and ash in the feed sample were analyzed according to AOAC (1990). Cows were milked twice daily and milk yield was measured daily. Once a week the milk samples from morning and afternoon milking were analyzed for the content of fat and protein. Once on day 18 of the experimental periods, milk samples were also analyzed for fatty acid composition. Protein and fat in milk were analyzed using a Foss MilkoScan. Fatty acids in milk were determined by gas chromatography (Chrom 5) on a fused silica capillary column coated with a Supelco-SP-216PS film as described by Man (1966).

On day 21 of each period jugular blood samples were collected from all cows $2 \mathrm{~h}$ after the morning feeding. Serum samples were prepared by centrifugation and stored at $-20^{\circ} \mathrm{C}$ before being analyzed for glucose, urea and cholesterol using Sigma kits.

Data were analyzed using StatGraph ver. 7.0 procedures.

\section{RESULTS AND DISCUSSION}

Chemical composition and nutritive value of feeds are given in Table 1. Rape seeds contained $404 \mathrm{~g}$ of ether extract in onc $\mathrm{kg}$ of DM and as a result the average cther extract concentrations increased by $22 \mathrm{lg}$ for dict MR, and by $439 \mathrm{~g}$ for diet HR because of the inclusion, respectively, of 0.7 or $1.4 \mathrm{~kg}$ WRS. Replacing con-

TABLE 1

Chemical composition and nutritive value of feeds, $\%$

\begin{tabular}{lcccc}
\hline Items & Concentrate & Rape seed & Maize silage & Hay \\
\hline DM \% as fed & 89.3 & 90.5 & 27.4 & 92.4 \\
Crude protcin & 15.62 & 18.46 & 2.59 & 10.4 \\
Ash & 3.12 & 3.52 & 1.26 & 4.52 \\
Crude fibre & 5.00 & 8.95 & 6.41 & 26.3 \\
Ether extract & 3.21 & 36.56 & 0.87 & 2.49 \\
PDIE & 10.62 & 3.07 & 1.64 & 6.74 \\
PDIN & 9.38 & 11.76 & 1.42 & 5.91 \\
UFL & 0.94 & 1.14 & 0.24 & 0.63 \\
\hline
\end{tabular}

IZ-INRA (1993): UFL-unit for milk production: PDl-protein truly digestible in the small intestine: PDIN -PDI dependent on $\mathrm{NH}_{3}-\mathrm{N}$ amount: PDIE-PDI dependent on energy amount 
centrate with WRS in the diet provided approximately $1.15 \%$ and $2.31 \%$ percentage units of additional fat in dry matter of the diet. Thus, the amount of fat in the HR dict did not exceed the 5-6\% unprotected fat recommended by Palmquist (1991). The average intake of pasture grass was approximately $44 \mathrm{~kg}(6.92 \mathrm{~kg} \mathrm{DM})$, maize silage $14 \mathrm{~kg}(3.87 \mathrm{~kg} \mathrm{DM})$ and meadow hay $2.5 \mathrm{~kg}(2.31 \mathrm{~kg} \mathrm{DM})$. Rape secds had no significant effect on the intake of maize silage and hay, similarly to the results of Hussein et al. (1996). Other researchers also indicated that dry matter intake was not affected by supplementing diets with ground or extruded rape seed as $3 \%$ added fat (Wiesen et al., 1989) or Jet-Sploded rape seeds (Khorasani et al., 1992). Gagliostro and Chiliard (1991) found that although fat supplementation lowered dry matter intake, energy intake was not decreased. Smith et al. (1978) concluded that gut fill, palatability or concentration of blood metabolites were not major factors limiting energy intake in diets containing protected tallow. The negative effect of fat on dry matter intake tends to increase as fat saturation decreases and as the amount of fat supplementation increases (Pantoja et al., 1996). The effect of added fat on voluntary feed intake seems to depend on the type of fat used, the way in which it is added, and the amount used (Clapperton and Steele, 1983). Stecle (1985) suggested that oil and fats exert an influence on DM consumption by physically preventing ruminal micro-organisms from gaining access to other dietary constituents or alternatively, free fatty acids released by hydrolysis may have toxic effects on some microbes, leading to altered populations within the rumen.

The administration of $1.4 \mathrm{~kg}$ rolled rape seeds (HR) (Table 2) per cow nonsignificantly increased the yield of milk, milk fat content $(\mathrm{P}<0.05)$ and significantly increased daily fat production by $89 \mathrm{~g}$ per day similarly to the results obtained by Clapperton and Stecle (1983). Strzetelski et al. (1992) found a higher FCM yield among cows fed control diets without rape seeds and formaldehyde- or heat-treated rape seeds.

TABLE 2

Mean daily milk yietd, fat and protein content in milk

\begin{tabular}{lcccc}
\hline \multirow{2}{*}{ Itcm } & \multicolumn{3}{c}{ Dicts } & SEM \\
\cline { 2 - 4 } & $\mathrm{CK}^{\prime}$ & $\mathrm{MR}^{2}$ & $\mathrm{HR}^{3}$ & \\
\hline Daily milk yield, kg & 18.4 & 18.9 & 19.6 & 3.67 \\
Fat, \% & 3.98 & 4.12 & 4.20 & 0.32 \\
Protein, \% & 3.10 & 3.03 & 3.04 & 0.28 \\
Fat, g/day & $733^{\mathrm{a}}$ & $779^{\mathrm{h}}$ & $822^{\mathrm{b}}$ & 91 \\
Protein, g/day & 571 & 573 & 595 & 45 \\
Fat+protein, g/day & $1304^{\mathrm{a}}$ & $1352^{\text {ah }}$ & $1417^{\mathrm{h}}$ & 151 \\
\hline
\end{tabular}

a.h $\mathrm{P}<0.05$

' CK - control

$2 \mathrm{MR}$ - with $0.7 \mathrm{~kg}$ rolled whole rape seeds

${ }^{3} \mathrm{HR}$ - with $1.4 \mathrm{~kg}$ rolled whole rape seeds 
Murphy et al. (1990) reported no significant effect of including 15\% unrolled whole rape seeds in the concentrate and a significant increase of cow performance as result of including the same amount of ground rape seeds. Shingoethe et al. (1996) recorded an increase of milk production as an effect of supplementing fat by using sunflower seeds and extruded soyabeans, and no significant effect on milk composition. On the other hand, Syrjällä-Qvist and Aspilla (1984) found no significant effect of added crushed canola secds on fat content, milk yield and protein level. Holter et al. (1992) suggested that the substitution of fat for some of the concentrate, even if it did not reduce total dry matter intake or digestion rate under ad libitum intake, would enhance encrgy intake and even prevent milk fat depression. In a previous experiment milk fat percentage was depressed in cows fed high-linoleic and high-olcic sunflower oil (Kalschuer et al., 1997), soyabean oil (Banks et al., 1980), whole sunflower seeds (Casper et al., 1988), and extruded soyabeans (Kim et al., 1991). Palmquist and Jenkins (1980) pointed out that polyunsaturated fatty acids in particular inhibit the growth of ruminal microbes, which can reduce microbial digestion of fibre, protein synthesis and volatile fatty acid (VFA) production as the fatty acid content in the ration increases, unless these fatty acids are made insoluble by saponification with $\mathrm{Ca}$.

In the present study, dairy cows received supplemental fat that tended to decrease the percentage of protein in milk, but total daily protein production was not affected by the treatment. In the experiment of Strzctelski et al. (1992), ground formaldehyde- or heat-treated rape seeds lowered the milk protein content, but these differences were not statistically significant. Holter et al. (1992) found a negative effect of whole cottonseed on milk protcin content, similarly to results obtained by Palmquist and Jenkins (1980), Coppock et al. (1987), and Khorasani et al. (1991). Casper and Shingocthe (1989) suggested that supplemental fat inhibits the release of somatotropin, thercby reducing mammary uptakc of amino acids. In contrast, Smith et al. (1978) stated that reduced VFA production can influence the synthesis of milk constituents, and milk protein synthesis usually does not decline during fat supplementation, but the depression in milk protein concentration, associated with dietary addition of fat is also related to reduced availability of glucose. Lower propionate production may increase the utilisation of amino acids available for milk synthesis. Khorasani ct al. (1991) supposed that lower milk protein content may be related to lower acetate production in the rumen, which could increase the utilisation of amino acids as an energy substrate.

Dietary manipulation is one of the factors altering the fatty acid composition of milk fat. Clinical research has indicated that $\mathrm{C}$ 18:1 present in rapeseed oil has a

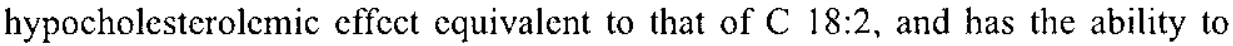
lower the risk of coronary heart disease (Noakes et al., 1996). Milk products that contain less saturated fatty acids and more unsaturated $\mathrm{C}: 18$ may be desirable to health-conscious consumers. In general, short-chain fatty acids are synthesized in 
the mammary gland, while long-chain fatty acids arise from mobilization of body reserves or from dietary sources. Rape seed has a unique fatty acid profile, $40 \%$ fat (unsaturated fatty acids) that consists primarily of oleic, $55 \%$, linolenic, $25 \%$, and linoleic acids, $14 \%$. The fatty acid composition of milk fat in our experiment was affected by including rolled whole rape secds (Table 3 ). There was a significant $(\mathrm{P}<0.05)$ increase of $\mathrm{C} 18: 1$ and $\mathrm{C} 18: 3$ content as a result of adding WRS, but no effect on the concentration of C 18:2. When Strzetelski et al. (1992) fed formaldehyde- or heat-treated ground rape sceds, they obtained a significant increase of C 18:1, C 18:2 and C 18:3 fatty acids in milk fat. Banks (1987) suggested that elevated levels of oleic acid in milk fat are due to either increased dictary C 18:1, as a result of partial rumen hydrogenation, or increased desaturation of $\mathrm{C}$ 18:0 in the gut wall and the mammary gland. These changes in milk unsaturated fatty acid composition and the lower content of C 18:0 were probably influenced by a relatively low rate of biohydrogenation of oleic and linoleic acids in the rumen, which is rather typical of incrt rumen fermentation sources of unsaturated fats. Changes in unsaturated fatty acids were not as great as those that occurred with abomasal infusion of oils (Christensen et al., 1994), demonstrating the biohydrogenation that occurred when WRS were fed in the present cxpcriment. A linear decrease in C 16:0, and linear increases in C 18:1, C 18:2

TABLE 3

Fatty acids composition of milk fat, $\mathrm{g}$ per $100 \mathrm{~g}$ of total fatty acids

\begin{tabular}{|c|c|c|c|c|}
\hline \multirow{2}{*}{ Fatty acids } & \multicolumn{3}{|c|}{ Diets $^{1}$} & \multirow{2}{*}{ SEM } \\
\hline & CK & MR & HR & \\
\hline C 4:0 & 2.8 & 3.1 & 3.2 & 0.12 \\
\hline$C 6: 0$ & 2.5 & 2.1 & 2.2 & 0.18 \\
\hline C 8:0 & 0.9 & 0.8 & 0.7 & 0.11 \\
\hline C 10:0 & 2.1 & 1.9 & 2.0 & 0.43 \\
\hline C 12:0 & 3.1 & 3.1 & 2.9 & 0.37 \\
\hline C 14:0 & 11.9 & 10.9 & 11.4 & 3.33 \\
\hline C 14:1 & 0.2 & 0.2 & 0.2 & 0.09 \\
\hline C 15:0 & 1.4 & 1.0 & 1.1 & 0.13 \\
\hline C 15:I & 1.1 & - & 1.4 & 0.18 \\
\hline C 16:0 & 29.4 & 27.6 & 28.0 & 9.38 \\
\hline C 16:1 & 1.6 & 0.9 & 2.1 & 0.27 \\
\hline C 17:0 & 0.1 & 0.1 & 0.1 & 0.02 \\
\hline C 18:0 & $13.8^{\circ}$ & $10.9^{\mathrm{h}}$ & $11.4^{\mathrm{h}}$ & 3.30 \\
\hline C 18:1 & $24.7^{\mathrm{a}}$ & $29.7^{\mathrm{b}}$ & $28.3^{\mathrm{b}}$ & 11.24 \\
\hline C 18:2 & 1.7 & 1.7 & 1.5 & 0.41 \\
\hline C $18: 3$ & $0.5^{\mathrm{a}}$ & $0.6^{\mathrm{a}}$ & $0.8^{\mathrm{b}}$ & 0,20 \\
\hline C 20:0 & $0.7^{a}$ & $1.6^{b}$ & $1.2^{\mathrm{c}}$ & 0.10 \\
\hline
\end{tabular}

a.h. $\mathrm{P}<0.05$

' 1 as in Table I 
and C 18:3 were observed (St John et al., 1987) after abomasal infusion of dairy cows with graded concentrations of rape seed oil. Kalscheur ct al. (1997) reported that addition of sunflower oil decreased percentages of $\mathrm{C}$ 14:0, C 15:0, C 16:0, C 17:0 and C 18:3, increased the concentration of cis C 18:1, and no change of C 18:2. Shingocthe et al. (1996) found significant changes of fatty acid composition by reducing saturated fatty acids from 71 to $60 \%$, and increasing polyunsaturated fatty acids from 2.3 to $4 \%$ as a result of including whole cottonseed and extruded soyabcans. Milk from cows fed whole cottonseed and Ca-tallowate in the experiment of Lubis et al. (1990) contained unsaturated fatty acids (mostly $\mathrm{C} 18: 1$ ) and lesser quantities of short-chain fatty acids. Chouinard et al. (1997) found that increasing the amount of dietary fat linearly decreases the proportion of C 12:0, C 14:0 and C 16:0 in milk. Inclusion of rape seeds in the diet improved the softness of milk fat by raising the iodine number and decreasing the melting points of milk fat (Murphy ct al., 1990).

Most previous studies (Bines et al., 1978) indicated that the plasma glucose concentration does not change when fat is fed to dairy cows. Our results (Table 4) confirm those of Khorasani et al. (1992) who found higher concentration of glucose in plasma as an effect of including canola fat, as in our experiment. In the present study, total serum cholesterol increased as the level of WRS inclusion increased. Khorasani et al. (1992) observed a positive relationship between serum cholesterol and dietary fat, however, Schneider et al. (1988) reported no change in plasma cholesterol when inert fat was fed to lactating cows. These results suggest that the impact of dietary fat on plasma cholesterol concentration will vary, depending on the dietary level of fat and type of diet.

TABLE 4

The effect of dietary addition of rolfed rape sceds on plasma metabolites, mmol/]

\begin{tabular}{lllll}
\hline & \multicolumn{3}{c}{ Dicts $^{\prime}$} & \\
\cline { 2 - 4 } Item & $\mathrm{CK}$ & $\mathrm{MR}$ & $\mathrm{HR}$ & SEM \\
\hline Glucose & $2.86^{\mathrm{n}}$ & $3.07^{\mathrm{a}}$ & $3.4 \mathrm{1}^{\mathrm{h}}$ & 0.24 \\
Urea & 2.31 & 2.34 & 2.12 & 0.17 \\
Cholesterol & $2.30^{\mathrm{n}}$ & $3.60^{\mathrm{h}}$ & $3.48^{\mathrm{h}}$ & 0.67 \\
\hline
\end{tabular}

a.h $\mathrm{P}<0.05$

'as in Table I

The results of our experiments suggest that feeding lipid in the form of rolled rape seeds improves its chances of escaping biohydrogenation in the rumen and more rumen by-passed lipids would be digested in the intestine. The results of the present study indicate that use of WRS would result in positive changes in the fatty acid composition without negative effects on milk production. 


\section{CONCLUSIONS}

Rolled whole rape sceds used at a level of $0.7-1.4 \mathrm{~kg} /$ day per cow can substitute for a part of concentrate in feeding high yiclding cows in the first part of lactation. The fecding of rolled rape seeds rich in unsaturated fatty acids can have a beneficial effect on fatty acid composition of milk fat. The inclusion of rolled rape seeds also increased serum glucose and total cholesterol concentrations.

\section{REFERENCES}

Association of Official Analytical Chemists, 1990. Official Methods of Analysis. $15^{1 / 2}$ Edition. Arlington, VA

Baer R.J.. 1991. Alteration ol fatty acids content of milk fat. J. Food Protect. 54, 383-390

Banks W.. 1987. Opportunities for varying the composition of cow's milk. J. Soc. Dairy Tech. 40, 96-99

Banks W., Clapperton J.L., Kelly M.E., Wilson A.G., Crawford J.M., 1980. The yield, fatty acids composition and physical properties of milk fat obtained by feeding soya oil to dairy cows. J. Sci. Food Agr. 31, 368-376

Bines J.A., Brumby P.E., Storry J.E., Fulford R.J., Braithwaite G.D., 1978. The effect of protected lipids on nutrient intakes, blood and rumen metabolites and milk secretion in dairy cows during carly lactation. J. Agr. Sci. 65, 135-143

Casper D.P., Shingoethe D.J., 1989. Mode! to describe and alleviate milk protein depression in carly lactation dairy cows fed high fat diet. J. Dairy Sci. 72, 3327-3335

Casper D.P., Shingoethe D.J, Middaugh R.P., Baer R.J., 1988. Lactational responses of dairy cows to diets containing regular and high oleic acid sunflower seeds. J. Dairy Sci. 7I, 1267-1275

Chouinard P.Y.. Girard V., Brisson G.J., 1997. Laclational response of cows to different concentrations of calcium salts of canolia oil fatty acids with or without bicarbonates. J. Dairy Sci. 80 , 1185-1193

Christensen R.A., Drackley J.K., La Count D.W., Clark J.H., 1994. Infusion of four long-chain fatty acid mixtures into abomasum of lactating cows. J. Dairy Sci. 71, 1267-1278

Clapperton J.L., Steele W., 1983. Fat supplementation in animal production - ruminants, Proc. Nutr. Soc. 41, 343-350

Coppock C.E., Lanham J.K., Horner J.L., 1987. A review of the nutritive value and utilisation of whole cottonseed, cottonseed meal and associated by-products by dairy cattle. Anim. Feed Sci. Tech. 18, 89-129

Gagliostro G., Chilliard Y., 1991. Duodenal rapeseed oil infusion in early and midlactation cows. 2.Voluntary intake, milk production, and composition. J. Dairy Sci. 74, 499-509

Gawęcki K., 1994. Instructions for Animal Nutrition and Feeds Evaluation (in Polish). Poznan Agricultural University Press, Poznań (Poland)

Holter J.B., Hayes H.H. Urban E.E.. 1992. Energy balance and lactational response in Holstein cows supplemented with cottonseed with or without calcium soap. J. Dairy Sci. 75, 1480-1494

Hussein H.S., Merchen N.R., Fahey G.C., 1996. Effects of chemical treatment of whole canola secd on digestion of long-chain fatly acids by steers fed high or low forage diets. J. Dairy Sci. 79, 87-97

IZ-INRA, 1997. Standards for Cattle, Sheep and Goat Nutrition (in Polish). Research Institute of Animal Production, Kraków. Omnitech Press, Warszawa (Poland) 
Kalschuer K.F., Teter B.B., Piperova L.S., Erdman R.A., 1997. Effect of source on duodenal flow of trans C-18:1 fatty acids and milk fat production in dairy cows. J. Dairy Sci. 80, 2115-2126

Khorasani G.R.. de Boer G.. Robinson P.H., Kennely J.J., 1992. Effect of canola fat on ruminal and total tract digestion, plasma hormones, and metabolites in lactating dairy cows. J. Dairy Sci. 75 , 492-501

Khorasani G.R., Robinson P.H., De Bocr G., Kennelly J.J., 1991. Intluence of canola fat on yield, fat percentage tatty acid protile, and nitrogen fractions in Holstein milk. J. Dairy Sci. 74, 1904-1911

Kim Y.K.. Shingoethe D.J., Casper D.P., Ludens F.C., 1991. Lactational response of dairy cows to increased dietary crude protein with added fat. J. Dairy Sci. 74, 3891-3899

Kowalczyk J., Ørskov E.R., Robinson J.J., Stewart, C.S., 1977. Effec1 of fat supplementation on voluntary intake and rumen metabolism in sheep. Brit. J. Nutr. 37, 25 1-257

Lubis D., Van Horn H.H., Harris B., Bachman K.C., Emmanuelle S.M., 1990. Responses of lactating dairy cows to protected fats or whole coltonseed in low or high foragc diets. J. Dairy Sci. 73, $3512-3525$

Man J.M., 1966. Determination of fatty acids composition of milk fat by dual temperature programmed gas-liquid chromatography. J. Dairy Sci. 47, 546-548.

Murphy J.J., McNeill G.P., Connoly J.F., Gleeson P.A., 1990. Effect of cow performance and milk fat composition of including full fat soybeans and rapeseeds in the concentrate mixture for lactating cows. J. Dairy Res. 57, 295-306

Murphy M., Uden P., Palmquist D.L, Wiktorson H., 1987. Rumen and total digestibilities in lactating cows fed diets containing full-fat rapeseed. J. Dairy Sci. 70, 1572-1582

Noakes M., Nestel P.J.. Clifton P.M., 1996. Modifying the fatty acids profile of dairy products through teedlot technology lowers plasma cholesterol of humans consuming the products. Amer. J. Clin. Nutr. 63, 42-46

Nowak W., 1997. Dry matter and ADF disapperance from wheal straw and wood cellulose estimated by ,in sacco" method. International Seminar, ,I $n$ vilro and in vivo Methods Used in Experiments on Digestion Processes and Feed Evaluation". Rescarch Institute of Animal Production, Kraków (Poland), pp. 46-48

Palmquist D.L.. 1991. Influence of source of dietary fat on digestibility in lactating cows. J. Dairy Sci. 74, 1354-1360

Palmquist D.L, Jenkins T.C., 1980. Fat in lactation rations : revicw. J. Dairy Sci. 63, 1-14

Pantoja J., Firkins J.J., Eastridge M.L., 1996. Fatty acid digestibility and lactation performance by dairy cows led fats varying in degree of saturation. J. Dairy Sci. 79, 29-437

Rafalowski W., Park C.S., 1982. Whole sunflower seed as a fat supplement for lactating cows. J. Dairy Sci. 34, 2209-2215

Schneider P., Sklan D., Chalupa W., Kronfeld D.S., 1988. Feeding calcium salts of fatty acids to lactating cows. J. Dairy Sci. 71, 2143-2150

Shingoethe D.J., Brouk M.J., Lightfield K.D., Baer R.. 1996. Lactational responses of dairy cows fed unsaturated fat from extruded soybeans or suntlower secds. J. Dairy Sci.79, 1244-124

Smith N.E., Dunkley W.L., Franke A.A., 1978. Effects of feeding canola meal-protectct-tallow to dairy cows in early lactation. Can. J. Anim. Sci. 64, 81-89

St John L.C., Young C.R., Knabe D.A., Thompson L.D., Schelling G.T., Grundy SM., Smith S.B., 1987. Fatty acids profiles and sensory and carcass traits of tissues from steers and swine fed an elevated monounsaturated fat diet. J. Anim. Sci. 64, 1441-1451

Strzctelski J.A.. Kowalczyk J., Krawczyk K., Stasiniewicz T., Lipiarska E., 1998a. Evening primrose (Oenothera paradoxa) oil cake or ground rape seed supplement to the diets for dairy cows. J. Anim. Feed Sci. 7, 365-375 
Strzetelski J.A., Kowalczyk J., Stasiniewicz T., Lipiarska E., Osięgłowski S., Bilik K., 1999. Milk yield and composition in dairy cows fed a diet with evening primrose (Oenothera paradoxa) full fat or oil cake. J. Anim. Fced Sci. 8, 89-94

Strzetelski J.A., Ryś R., Stasiniewicz T., Sroka M., Gawlik Z., 1992. The effect of feeding ground formaldehyde- or heat-treated rape seeds on cow performance and milk composition. J. Anim. Feed Sci.1, 97-105

Steele W., 1985. High oil, high protein diets and milk secretion by cows. J. Dairy Sci. 68, 1409-1415 Syrjällä-Qvist L., Aspila P. 1984. Rapeseed fat in dairy cow. J. Agr. Sci. Finland 56. 83-87

Wiesen B., Kincaid R.L.. Hillers J.K., Cronath J.D., 1989. Inciusion of whole edible rapeseed and rapeseed screening of lactating dairy cows. J. Dairy Sci. 72,487 (Abstr.)

\section{STRESZCZENIE}

\section{Wplyw gniecionych nasion rzepaku na wydajność i skład chemiczny mleka}

Przeprowadzono đoświadczenie na czterdzicstu pięciu krowach mlecznych w układzic 15 łączonych kwadratów lacińskich $3 \times 3$. Dawka kontrolna CK zawierała $6 \mathrm{~kg}$ mieszanki treściwej bez dodatku nasion rzepaku. dawki doświadczalne zawierały: MR $.5 \mathrm{~kg}$ mieszanki treściwej $+0,7 \mathrm{~kg}$ gniecionych nasion tzepaku (WRS), HR - $4 \mathrm{~kg}$ mieszanki treściwej + 1,4 kg gniecionych nasion rzepaku. Dodatek $1,4 \mathrm{~kg}$ nasion rzepaku do dawki złożonej z zielonki pastwiskowej, kiszonki z kukurydzy i siana spowodował zwiększenie wydajności mleka o 1,2 kg oraz dobowej produkcji tłuszczu o $89 \mathrm{~g}$. Stwierdzono przy tym tendencję do zmniejszenie procentowej zawartości białka w mlcku (CK-3,10\%, MR-3,03\%, HR-3,04\%), jednak dobowa produkcja białka nie różniła się istotnie pomiędzy dawkami. Dodatek tłuszczu spowodował istotne $(\mathrm{P}<0,05)$ zwiększenie udziału kwasów nienasyconych C 18:1 i C 18:3 w tłuszczu mleka. 